\title{
KUALITAS SEKSUAL WANITA YANG AKTIF OLAHRAGA DI KOTA MATARAM
}

\author{
Winda Nurmayani ${ }^{1}$, Dewi Nur Sukma Purqoti ${ }^{2}$, Elisa Oktaviani ${ }^{3}$, Syamdarniati $^{4}$ \\ 1,2,3,4 Program Studi Profesi Ners STIKES Yarsi Mataram \\ email: purqotidewi87@gmail.com
}

\begin{abstract}
Abstrak
Seksualitas memiliki peran mendasar dalam kehidupan reproduksi. Fungsi ini mengintegrasikan faktor fisik, emosional dan psikologis serta memengaruhi kualitas hidup. Permasalahan hubungan seksual bisa menjadi faktor yang menyebabkan buruknya hubungan dan berakibat pada perceraian. Untuk mengatasi masalah hubungan seksual diperlukan suatu kegiatan fisik yaitu olahraga, karena dengan berolahraga secara rutin baik pria dan wanita dapat membantu kelancaran hubungan intim dan kehidupan sek menjadi sehat. Tujuan penelitian ini adalah untuk mengetahui gambaran kualitas seksual wanita yang aktif olahraga di Kota Mataram. Penelitian ini merupakan penelitian deskriptif menggunakan desain crossectional melalui pendekatan case control dengan sampel sebanyak 55 orang wanita usia yang sudah menikah yang aktif melakukan olahraga yang berdomisili di Kota Mataram. Tehnik sampling pada penelitian ini simple random sampling dan pengumpulan data menggunakan instrument kuesioner $S Q O L-F$. Wanita yang aktif olahraga memiliki kualitas seksual yang baik, dengan kualitas seksual yang baik akan meningkatkan kepuasaan pasangan dan akan berefek positif terhadap kepuasaan perkawinan. Seluruh wanita yang berkeluarga diharapkan menerapkan pola hidup sehat dengan aktif berolahraga, dan diharapkan Pemerintah menyediakan fasilitas olahraga yang aman.
\end{abstract}

Kata kunci : kualitas seksual, olahraga, wanita

\begin{abstract}
Sexuality has a fundamental role in reproductive life, this function integrates physical, emotional and psychological factors and affects quality of life. The problem of sexual intercourse will effect to bad relationships and results in divorce. Exercise is one of physical activity to overcome the sexual intercourse problem, because by exercising regularly both men and women can help smooth intercourse and sexual life to be healthy. The purpose of this study is to describe the sexual quality of women who are active in sports in Mataram City. This is a descriptive research using cross sectional design through Case Control approach and sample were 55 married women who are actively doing sports domiciled in Mataram City. This study uses simple Random Sampling and data collection using SQOL-F questionnaire instrument. Women who are active in sports have good sexual qualities, with good sexual qualities will increase the satisfaction of the partner and will have a positive effect on marital satisfaction. All women with families are expected to adopt a healthy lifestyle by actively exercising, and it is expected that the Government provides safe sports facilities.
\end{abstract}

Keywords : sexual quality, sports, women

\section{PENDAHULUAN}

Perkawinan merupakan hubungan

lahir dan batin antara seorang laki-laki dan perempuan yang tertujuan menjadikan rumah tangga yang bahagia. Rumah tangga bahagia merupakan impian setiap pasutri meski begitu kadang kita temukan adanya rumah tangga yang kurang harmonis. 
Winda Nurmayani, Dewi Nur Sukma Purqoti, Elisa Oktaviani, Syamdarniati, Kualitas Seksual Wanita yang Aktif Olahraga di Kota Mataram

Akibat dari hal ini adalah berujung pada perpisahan atau perceraian (Dewanti \& Suprapti, 2014)

Perceraian berakibat fatal, antara lain adalah pecahnya ikatan kekeluargaan tersebut, renggangnya hubungan kekeluargaan dan yang paling fatal adalah dampak yang dirasakan oleh anak. Perceraian telah menyebabkan kenakalan remaja (Matodang, 2014)

Provinsi Nusa Tenggara Barat menjadi penyumbang status janda dan duda keempat terbesar di Indonesia. Hal ini ditunjukkan dengan semakin tingginya angka perceraian. Badan Koordinasi Keluarga Berencana Nasional (BKKBN) NTB menunjukkan, dari 1,430,359 kepala keluarga (KK) di NTB, 21,60 persen atau sebanyak 308,957 berstatus sebagai janda dan duda (Nur, 2016). Angka kejadian pernikahan dini atau perkawinan usia anak masih tinggi di Provinsi NTB, menurut data Badan Pemberdayaan Perempuan, Perlindungan Anak dan Keluarga Berencana (BP3AKB) NTB kasus perkawinan usia anak mencapai angka $34,9 \%$ dengan usia pendidkan yang masih duduk di bangku SMP-SMA (BP3AKB, 2015). Data dalam catatan tahunan (2018) terkumpul data bahwa kasus kekerasan dalam rumah tangga (KDRT) sudah mencapai angka $71 \%(9,609)$. Kekerasan seksual adalah ranah pribadi yang menjadi terbanyak kedua yang paling banyak dilaporkan (Sari \& Sularto, 2019). Berdasarkan data dari Pusat Pelayanan Terpadu Pemberdayaan Perempuan dan Anak (P2TP2A) Provinsi NTB, pada tahun 2016 tercatat 1.679 kasus KDRT dan meningkat pada tahun 2017 menjadi 1,821 kasus KDRT (P2TP2A, 2017). Dari data tersebut dipaparkan bahwa 70\% kasus yang dilaporkan adalah kasus kekerasan seksual (Masnun, 2019). Menurut Data dari Pengadilan Agama Kota Mataram, Jumlah perempuan menjanda di Kota Mataram makin meningkat setiap hari. Ini menyusul tingginya angka perceraian di daerah itu. Pengadian Agama Mataram mencatat, pada tahun 2018 setidaknya ada 1,700 perkara yang ditangani. Setiap hari setidaknya ada 5 sampai 10 perkara cerai diputuskan oleh majelis. Humas Pengadilan Agama Mataram, Muhammad mengatakan penyebab banyaknya pasangan yang mengajukan gugatan cerai khusus di Kota Mataram yang didominasi oleh masalah perselingkuhan.

Salah satu penyebab utama dari perselingkuhan adalah adanya ketidakpuasan dalam perkawinan. Ketidakpuasan itu disebabkan kebutuhan seks yang tidak terpenuhi dalam perkawinan tersebut. Masalah seksual termasuk antara lain rasa sakit, lubrikasi, gairah seksual dan juga gangguan 
keinginan. Beberapa masalah tersebut bisa memberikan efek negatif pada kesehatan emosi dan juga kualitas hidup. Salah satunya penyakit seksual adalah disfungsi seksual. Dua dari lima wanita setidaknya mengalami masalah tersebut tanpa melihat faktor usia, yang dapat memberikan dampak negatif terhadap kualitas hidup dan kesehatan emosi. Disfungsi seksual adalah penyakit yang umum dimana dua dari lima wanita memiliki setidaknya satu jenis disfungsi seksual, dan keluhan yang paling banyak terjadi adalah rendahnya gairah seksual/libido (Michael A, 2007).

Topik tentang pernikahan tidak terlepas dari pembicaraan tentang hubungan intim pasangan karena hubungan intim merupakan salah satu kebutuhan biologis individu. Hubungan seksual adalah faktor penting untuk menjaga keharmonisan dan kebahagiaan rumah tangga. Permasalahan hubungan seksual bisa menjadi faktor yang menyebabkan buruknya hubungan dan berakibat pada perceraian.

\section{Puncak kebahagiaan dan} keharmonisan pada sebuah keluarga adalah lancarnya hubungan seksual sehingga pasutri haruslah bisa menikmati hubungan tersebut. Seks yang berujung ketidakpuasan bisa menyebabkan perselisihan dan juga perceraian (Manuaba, 2010). Seks adalah fungsi utama manusia dan memiliki peran mendasar dalam kehidupan reproduksi. Fungsi ini mengintegrasikan faktor fisik, emosional dan psikologis serta memengaruhi kualitas hidup. Ada berbagai macam hal yang dapat menyebabkan menurunnya kualitas seksual pada wanita usia subur. Selain karena faktor penyakit, usia dan stres, konsumsi obat.

Berolahraga secara rutin baik pria dan wanita dapat membantu kelancaran hubungan intim dan kehidupan sek menjadi sehat menurut Lawrence Sigel, seorang psikolog klinis yang di kutip dari Paste Magazine (24/5/2017). Hal ini karena fungsi seksual melibatkan fisiologis, psikologis dan emosional. Dengan olahraga akan membantu ketiga poin tersebut untuk mencapai kepuasan maksimal termasuk kepuasan seksual. Studi yang dilaksanakan di University of Texas di Austin Amerika Serikat menemukan, olahraga dapat meningkatkan gairah genital pada wanita yang sehat.

Pakar-pakar kesehatan menyarankan untuk mengatasi problematika seksual antara pasangan suami-istri adalah dengan berolahraga secara teratur. Sehatnya kehidupan seksual bisa terlihat baik secara psikis maupun fisik seperti yang dinyatakan oleh Rahmawati dalam (Kanca, 2014).

Bentuk olahraga yang diperlukan seorang wanita guna mengatasi masalah seksualitasnya ialah dengan berlatih untuk 
Winda Nurmayani, Dewi Nur Sukma Purqoti, Elisa Oktaviani, Syamdarniati, Kualitas Seksual Wanita yang Aktif Olahraga di Kota Mataram

menguatkan otot vagina, perut, punggung, paha, dan juga pantat sebagaimana yang dinyatakan oleh Pangkahila, 2004 dalam (Kanca, 2014). Salah satu olahraga yang disukai oleh wanita yang sudah berkeluarga adalah olahraga senam. Banyak latihan yang dilakukan di sebuah sanggar senam tergantung dari jenis latihan dan tujuan dari senam tersebut.

\section{Olahraga memegang peranan} penting dalam kualitas seksual wanita, oleh karena itu peneliti tertarik untuk mengkaji tentang kualitas seksual wanita yang aktif olahraga di Kota Mataram.

\section{METODE PENELITIAN}

Penelitian ini adalah penelitian yang bersifat deskriptif analitik menggunakan desain cros sectional dengan pendekatan case control dengan sampel sebanyak 54 orang wanita menikah yang aktif melakukan olahraga dan berdomisili di Kota Mataram. Tehnik sampling pada penelitian ini ada simple random sampling dan pengumpulan data menggunakan instrumen kuesioner $S Q O L-F$. Instrumen yang digunakan pada studi ini ialah kuesioner The sexual quality of life-female (SQOL-F) oleh Pakpour et al., (2013) dimana pada kuesioner ini terdapat 18 pertanyaan tentang kualitas seksual wanita yang telah dimodifikasi oleh peneliti. Nilai yang diberikan berdasarkan jawaban yang diberikan dari pernyataan favorable dan unfavorable dengan item jawaban (selalu, sering, kadang-kadang dan tidak pernah). Selanjutnya dari 18 pertanyaan mengklasifikasikan kualitas seksual pada tiga tingkat: Baik (49-72), Sedang (25-48) dan Buruk (18-24). Selanjutnya dilakukan analisis data univariat.

\section{HASIL PENELITIAN}

Tabel 1

Distribusi karaktristik responden

\begin{tabular}{lcc}
\hline Karakteristik Responden & Jumlah (n) & Persentase $(\%)$ \\
\hline Usia (Tahun) & 7 & 13 \\
$21-30$ & 34 & 63 \\
$31-40$ & 10 & 18,4 \\
$41-50$ & 2 & 3,7 \\
$51-60$ & 1 & 1,9 \\
$61-70$ & & \\
Usia menikah & 30 & 55,6 \\
$\leq 24$ tahun & 24 & 44,4 \\
$>24$ tahun & & \\
Menikah Ke & 52 & 96,3 \\
Pertama Kali & 2 & 3,7 \\
Kedua Kali & &
\end{tabular}




\begin{tabular}{lcc}
\hline Karakteristik Responden & Jumlah (n) & Persentase (\%) \\
\hline Jumlah Anak & 5 & \\
Tidak Punya & 36 & 9,3 \\
1-2 Orang & 13 & 24,6 \\
Z3 Orang & & Persentase (\%) \\
\hline Karakteristik Responden & Jumlah (n) & 50 \\
Jenis Olahraga & & 50 \\
$\quad$ Jalan pagi/sore teratur & 27 & 96,3 \\
Senam & 27 & 3,7 \\
Kualitas Seksual & 52 & 100 \\
$\quad$ Baik & 2 & \\
Sedang & 54 & \\
\hline Total & &
\end{tabular}

Pada tabel 1 diperoleh informasi bahwa jumlah distribusi usia responden antara usia 21 sampai 65 tahun, dimana distribusi usia paling banyak adalah 31-40 tahun dengan 34 responden (63\%). Karakteristik responden terbanyak berdasarkan usia menikah, didapatkan hasil 30 responden $(55,6 \%)$ yang menikah pada usia $\leq 24$ tahun. Distribusi responden terbanyak yaitu pernikahan pertama kali sebanyak 52 responden (96,3\%). Berdasarkan jumlah anak, sebagian besar responden memiliki anak 1-2 orang yaitu 36 responden $(66,6 \%)$. Jenis olah raga yang dilakukan oleh responden sama banyak antara jalan pagi/sore teratur dengan senam yakni 50 orang (50\%). Berdasarkan kualitas seksual, diketahui mayoritas responden memiliki kualitas seksual baik yaitu 52 orang $(96,3 \%)$.

\section{PEMBAHASAN}

Berdasarkan teori Kanca (2014), olahraga penting untuk meningkatkan kualitas seksual seseorang. Salah satu bentuk olahraga yang di sarankan buat wanita yang sudah berkeluarga yaitu senam seks (kegel exercise). Pelatihan senam seks yang dilakukan dengan teratur dan terus menerus akan berpengaruh positif pada peningkatan kondisi fisik, psikis dan sosial. Hal ini dikarenakan kebugaran akan tetap terjaga dan lebih meningkat sehingga terhindar dari stress dan penyakit yang bisa mengganggu aktivitas. Terdapat beberapa manfaat senam seks antara lain:

(1) meningkatkan respon seksual pada pelvis atau otot panggul, meningkatkan kuantitas dan kualitas seks, (3) meningkatkan kuantitas orgasme secara teratur, (4) meningkatkan tonus otot vagina, (5) meningkatkan vaskularisasi sehingga meningkatkan potensi orgasme, (6) membentuk dan memperbaiki jaringan otot vagina, (7) memudahkan wanita supaya bisa siap melahirkan, (8) mengurangi sakit punggung serta bisa meningkatkan 
Winda Nurmayani, Dewi Nur Sukma Purqoti, Elisa Oktaviani, Syamdarniati, Kualitas Seksual Wanita yang Aktif Olahraga di Kota Mataram

kenikmatan hubungan seks pasangan suami-istri.

Hasil penelitian pada 34 responden menunjukkan $(63 \%)$ berada pada rentang usia 31-40 tahun dimana kualitas seksual wanita cenderung baik, hal ini dikarenakan oleh gairah seksual pada usia tersebut masih sangat tinggi, dan wanita pada usia ini sedang dalam fase mencari tahu tentang hasrat untuk berhubungan seksual dan bagaimana cara yang nyaman untuk melakukannya. Orbuch, (2009), menyatakan bahwa wanita pada usia ini memiliki rasa percaya diri yang tinggi akan kehidupan seksualnya. Wanita cenderung merasa yakin bisa memberikan pasangannya kepuasan saat berhubungan seksual, hal ini dikarenakan wanita sedang mencari tahu tentang hasrat seksual, bagaimana cara mengkomunikasikannya dengan pasangannya, bagaimana cara menyalurkan hasrat seksual sampai mencapai titik orgasme.

Responden dalam penelitian ini sebagian besar menikah pada usia $\leq 24$ tahun $(55,6 \%)$. Pada umur ini terdapat perubahan fisik dan juga psikologis pada waktu antara lain perubahan pada sistem endokrin. Pada sistem endokrin terjadi peningkatan aktivitas kelenjar kelamin yang berakibat pada ketidakseimbangan sementara dari seluruh sistem kelamin pada masa awal remaja. Kelenjar-kelenjar seks berkembang pesat dan mulai berfungsi meski belum matang sampai pada akhir masa remaja atau awal dewasa muda. Organ-organ seksual yang telah matang ini mulai berfungsi dan membutuhkan penyaluran. Pada masa ini terjadi banyak perubahan baik secara fisik dan psikologis yang terjadi pada remaja, salah satu perubahan tersebut ialah perubahan sistem endokrin. Pada sistem endokrin terjadi peningkatan kegiatan kelenjar kelamin pada masa remaja yang menyebabkan ketidakseimbangan, sementara dari seluruh sistem kelamin pada masa awal remaja. Kelenjar-kelenjar seks berkembang pesat dan mulai berfungsi, meskipun belum mencapai ukuran yang matang sampai akhir masa remaja atau awal dewasa muda (Jafar, 2005).

Menurut penelitian Wardhani (2012), hasrat seksual akan muncul bersamaan dengan dimulainya masa pubertas pada remaja, rasa ingin tahu yang tinggi dan fantasi seksual menyebabkan remaja ingin melakukan hubungan seksual seperti yang orang dewasa lakukan. Sehingga pada usia ini remaja sudah bisa melakukan pernikahan untuk mencegah kehamilan tidak diinginkan.

Distribusi responden terbanyak yaitu pernikahan yang pertama kali $(96,3 \%)$. Aspek penting lainnya dalam kehidupan 
pernikahan adalah unsur untuk memenuhi kebutuhan biologis masing-masing dalam hal ini kebutuhan seksual. Kehidupan seksual, harus diperhatikan dengan baik, karena dapat menjadi pemicu pertengkaran bahkan perceraian dalam keluarga. Sebaiknya, masing-masing individu dalam pasangan harus memperhatikan keseimbangan kebutuhan seksual (Lehmiller, 2014).

Dalam pernikahan, kepuasan seksual merupakan faktor pemelihara pernikahan. Kepuasan seksual merupakan sumber dari kekuatan pernikahan dan juga dapat menimbulkan konflik dalam pernikahan (Helgeson, 2012). Oleh karena itu hubungan seksual yang ideal adalah hubungan seksual yang dilakukan pasangan suami istri yang terikat dalam pernikahan sah dan masing-masing individu memiliki unsur passion, intimasi, dan komitmen sepanjang masa (Asmarina \& Lestari, 2017). Pasangan suami istri yang bahagia juga merasa bahwa pasangannya tidak akan menolak atau melakukan perilaku seksual yang kurang menyenangkan (Olson \& DeFrain, 2003). Dalam sebuah komunikasi, aspek-aspek kepuasan, pengungkapan seksual serta keseimbangan kedudukan seksual (Byers \& Wang, 2004).

Pada penelitian ini rata-rata responden memiliki 1-2 orang anak (66,6\%), kehadiran anak bisa mempengaruhi hubungan seksual antara suami istri. Menurut penelitian Srisusanti dan Zulkaida (2013) anak merupakan faktor yang cukup mempengaruhi kehidupan dan kepuasan perkawinan, kehadiran anak-anak dalam perkawinan membangun perasaan yang semakin dekat dengan pasangannya.

Karakteristik responden berdasarkan jenis olahraga yang sering dilakukan yakni jalan pagi atau sore teratur dan juga senam masing-masing (50\%). Senam merupakan suatu rangkaian gerak dalam senam pembentukan, khususnya pada bagian panggul, paha serta perut (Listyarini. Orakas dalam (Kanca, 2014) mendefinisikan bahwa senam seks merupakan olahraga untuk menguatkan potensi seks bagi seorang pria maupun wanita serta untuk menstabilkan, melakukan ataupun meningkatkan kemampuan bersenggama (coitus), meningkatkan ketahanan dalam aksi coitus, kemampuan berereksi dan juga orgasme yang sempurna, serta berguna untuk mengurangi kelelahan yang disebabkan oleh coitus yang mengurangi kekuatan tubuh, sehingga kehidupan yang terasa semakin lama semakin layu akan segar kembali, dengan demikian akan menunjang kebahagiaan dan kemesraan serta kerukunan rumah tangga.

Karakteristik responden dengan suami berolahraga sebanyak $(59,3 \%)$ dan 


\section{Winda Nurmayani, Dewi Nur Sukma Purqoti, Elisa Oktaviani, Syamdarniati, Kualitas Seksual Wanita yang Aktif Olahraga di Kota Mataram}

yang tidak berolahraga sebanyak 22 $(40,7 \%)$. Olahraga adalah sebuah perilaku aktif untuk meningkatkan kekebalan tubuh dengan cara meningkatkan metabolisme dan mempengaruhi fungsi kelenjar di dalam sehingga dapat menjadi proteksi bagi tubuh dari gangguan mikroorganisme yang menyebabkan penyakit termasuk di dalamnya adalah mempertahankan tubuh dari stres. Satiadarma dalam Kanca (2014) mengatakan bahwa olahraga merupakan aktivitas yang sangat penting dilakukan secara rutin untuk mempertahankan kebugaran tubuh. Berolahraga yang teratur akan menjadikan seseorang lebih mempunyai semangat dan terlihat lebih muda dari usianya, dan berolahraga juga dapat menghilangkan ketegangan, stres dan ketakutan yang berlebihan yang mungkin dapat mengganggu kenikmatan dalam berhubungan coitus. Olahraga juga membuat sirkulasi darah menjadi lebih lancar (Fox dalam Kanca, 2014), termasuk aliran darah yang menuju titik-titik peka yang mampu meningkatkan gairah seks. Kesehatan fisik dan psikis merupakan modal utama untuk dapat melakukan aktivitas seksual dengan optimal, sehingga akan mempererat hubungan suami istri. Hal ini sesuai dengan penelitian yang dilakukan oleh Brezsnyak dan Whisman, (2004) bahwa ada pengaruh kepuasaan seksual terhadap kepuasaan perkawinan.
Pasangan suami-istri yang memiliki kebugaran seksual yang baik akan memiliki kualitas seksual yang lebih baik bila dibandingkan dengan pasangan suami-istri yang memiliki kebugaran seksual yang lebih jelek pada kondisi yang sama. Kehidupan seksual yang sehat biasanya terdapat pada pasangan yang sehat pula baik secara fisik maupun psikis. Jika salah satu merasa tidak bugar (fit), loyo dan staminanya menurun bahkan merasa sakit, maka aktivitas seksual tidak akan optimal, demikian pula dengan keadaan psikisnya, bila ada masalah dan banyak pikiran maka aktivitas seksualnya tidak akan berjalan dengan optimal. Gairah seks bertambah berkat aktivitas olahraga yang teratur, sebab olahraga terbukti mampu meningkatkan kadar hormon testoteron bagi laki-laki dan hormon estrogen bagi perempuan dimana kedua hormon tersebut memberi pengaruh langsung terhadap kemauan dan kepuasan seksual. Dengan melakukan olahraga sesuai dengan takaran yang benar akan dapat meningkatkan kebugaran jasmani seseorang. Dengan meningkatkan kebugaran jasmani, maka semua fungsi alat tubuh akan membaik, tidak terkecuali fungsi alat alat kelamin baik pria maupun wanita, dengan demikian kemauan dan aktivitas seksual akan meningkat serta frekuensi bermain akan menjadi lebih baik (Kanca, 2014). 
Hal ini sejalan dengan Hasil penelitian Ansori, Muhammad, dan Satya (2016) yang menyatakan bahwa terdapat relasi antara senam ergonomik pada kualitas hubungan seksual pada lanjut usia. Terapi non farmakologi berguna untuk memperbaiki kualitas hubungan seksual lansia melalui senam ergonomis. Senam ergonomik dapat meningkatkan dan melancarkan sirkulasi darah supaya suplai darah menuju organ intim menjadi lancar. Akibat dari hal ini penis menjadi mudah ereksi, sedangkan labia minora dan klitoris akan lebih sensitif terhadap rangsang seksual.

\section{SIMPULAN}

Wanita yang aktif olahraga memiliki kualitas seksual yang baik, dengan kualitas seksual yang baik akan meningkatkan kepuasaan pasangan dan akan berefek positif terhadap kepuasaan perkawinan. Wanita yang aktif berolahraga mempunyai kualitas seksual yang baik. Dari 54 responden 52 (96,3\%) mempunyai kualitas seksual yang baik, hanya 2 wanita $(3,7 \%)$ yang mempunyai kualitas seksual yang sedang. Latihan adalah metode yang efektif untuk meningkatkan situasi psikis dan fisik seseorang sehingga bisa terhindar dari berbagai penyakit serta stress yang dapat mengganggu aktivitas seksual.

\section{SARAN}

Diharapkan seluruh wanita yang menikah menerapkan pola hidup sehat dengan aktif berolahraga untuk meningkatkan kualitas seksual. Selanjutnya pemerintah menyediakan fasilitas olahraga yang aman, menjadwalkan, mendatangkan instruktur senam yang profesional untuk menarik minat masyarakat untuk berolahraga.

\section{DAFTAR PUSTAKA}

Ansori, M, Pratiwi., Yunita, S, B., \& Tri C. (2016). Pengaruh senam ergonomik terhadap kualitas hubungan seksual pada lansia di posyandu jambu 30 Desa Pancakarya Kecamatan Ajung Kabupaten Jember. Universitas Muhammadiyah Jember.

Asmarina, N. L. P. G. M., \& Lestari, M. D. (2017). Gambaran kepercayaan, komitmen pernikahan dan kepuasan hubungan seksual pada istri dengan suami yang bekerja di kapal pesiar. Jurnal Psikologi Udayana, 4(2), pp. 239-249.

BP3AKB. (2015). Data statistic perkawinan anak NTB. in. DBP3AKB.

Brezsnyak, M., \& Whisman, M. A. (2004). Sexual desire and relationship functioning: The effects of marital satisfaction and power. Journal of Sex \& Marital Therapy, 30(3), pp. 199-217.

Byers, E. S., \& Wang, A. (2004). Understanding sexuality in close relationships from the social exchange perspective.

Dewanti, A., \& Suprapti, V. (2014). Resiliensi remaja putri terhadap problematika pasca orang tua bercerai. Jurnal psikologi pendidikan dan perkembangan, 3(3), pp. 164171.

Helgeson, V. S. (2012). Gender and health 
Winda Nurmayani, Dewi Nur Sukma Purqoti, Elisa Oktaviani, Syamdarniati, Kualitas

Seksual Wanita yang Aktif Olahraga di Kota Mataram

a social psychological perspective.'

Kanca, I. N. (2014). Pengaruh pelatihan olahraga senam seks terhadap wanita berumahtangga. Jurnal Penjakora, 1(1), pp. 1-15.

Manuaba, I. B. G. (2010). Ilmu kebidanan, penyakit kandungan dan keluarga berencana. Jakarta: EGC, 15, p. 157.

Masnun. (2019). Ketika NTB darurat kekerasan terhadap perempuan. Ataranews (9 Maret).

Matondang, A. (2014). Faktor-faktor yang mengakibatkan perceraian dalam perkawinan. JPPUMA Jurnal Ilmu Pemerintahan dan Sosial Politik Universitas Medan Area, 2(2), pp. 141-150.

Michael, C.A. (2007). Induction of labour impact on operative delivery, $\mathrm{XV}$ th Asia and oceanic congress of obstetrics and gynecology.

Nur, H. (2016). Jumlah janda-duda di NTB peringkat empat terbanyak nasional. Gatracom.

Olson, D. H. L., \& DeFrain, J. D. (2003). Marriages and families: Intimacy, strengths, and diversity. McGrawHill.

Orbuch, T. L. (2009). 5 Simple steps to take your marriage from good to great. Delacorte Press.

P2TP2A. (2017). Data statistic kasus KDRT Provinsi NTB. Dokumentasi (Mataram: P2TP2A Provinsi Nusa Tenggara Barat, 2017). in. P2TP2A Provinsi Nusa Tenggara Barat.

Pakpour, A. H. et al. (2013). Psychometric Properties Of The Iranian Version Of The Sexual Quality Of Life Scale Among Women. The journal of sexual medicine, 10(4), pp. 981-989.

Sari, A. A. \& Sularto, R. B. (2019). Kebijakan formulasi kekerasan seksual terhadap istri (Marital Rape) berbasis keadilan gender di Indonesia. Jurnal Pembangunan Hukum Indonesia, 1(1), pp. 117-127.

Srisusanti, S., \& Zulkaida, A. (2013). Studi deskriptif mengenai faktor-faktor yang mempengaruhi kepuasan perkawinan pada istri. UG journal, 7(6).

Wardhani, D. T. (2012). Perkembangan dan seksualitas remaja. Sosio Informa, 17(3). 